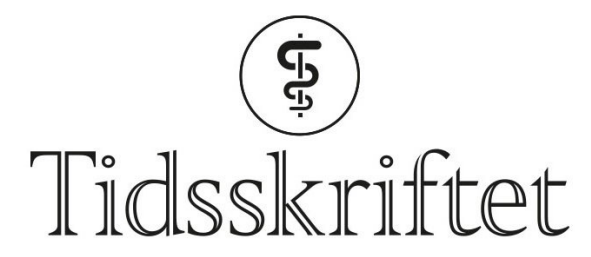

DEN NORSKE LEGEFORENING

\title{
Rett mann på rett plass til rett tid
}

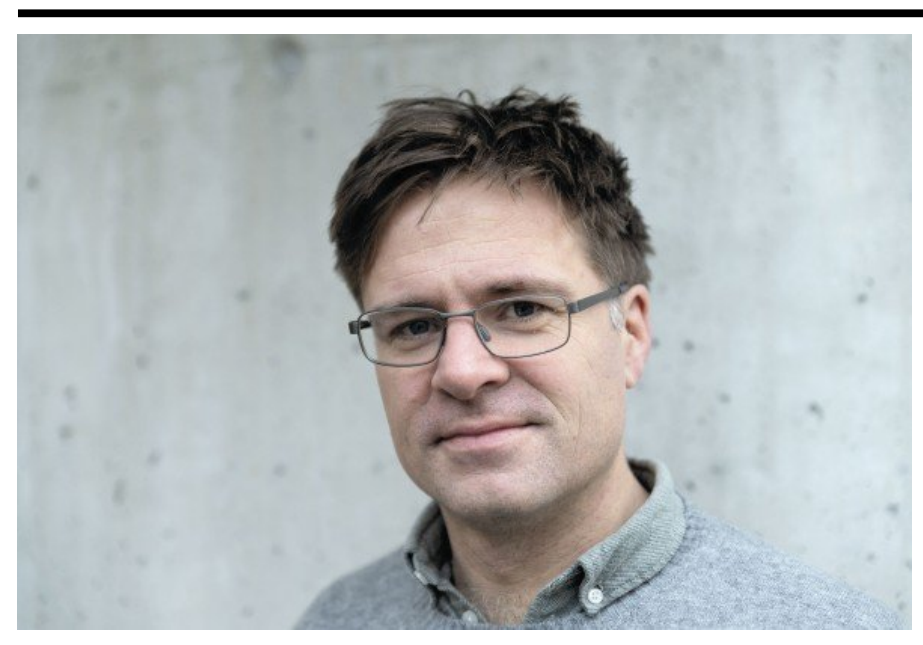

INTERVJU

JANNIKE REYMERT

E-post: jannike.reymert@gmail.com

Christian Ohldieck har hatt en stor plass i utviklingen av legemiddelassistert rehabilitering både i Bergen og nasjonalt. Han sier at karriereveien mest handler om tilfeldigheter, men hans gode teft og evne til å tenke nytt har nok vært viktige faktorer på veien.

Avdeling for rusmedisin i Bergen holder hus på kaikanten innerst i Bergen havn, med en fantastisk utsikt mot Bryggen og tilliggende herligheter. Christian kommer heseblesende inn døra til avtalt tid. Han motbeviser dermed det en kollega av ham spådde da jeg kom litt for tidlig. «Han er ikke alltid god til å komme tidsnok», sa vedkommende, før hun skjønte at det kanskje ikke var en fin måte å presentere sin kollega på. Så hun la til: «Han er så populær, skjønner du, det er alltid noen som skal ha et ord med ham og han er dårlig på å si nei når noen spør.»

Christian går rett på sak.

- Jeg trodde jeg skulle bli allmennlege, som jeg også var i noen år, men så fikk jeg tilfeldigvis tilbud om en stilling innen rus- og avhengighetsbehandling. For meg var dette et ungt og spennende fagfelt, stiene var ikke tråkket opp enda. Det var få leger på feltet og jeg fikk raskt rolle som overlege - på godt og vondt. Det krevde at jeg mestret å jobbe selvstendig.

Begynnelsen av Christians karriere sammenfalt med rusreformen der rusmiddelavhengige fikk pasientrettigheter.

- Da utviklet faget seg nærmest eksplosivt. Jeg synes jeg er heldig som har fått være med på å bidra i denne utviklingen. 


\section{Nygårdsparken}

I Bergen ble Nygårdsparken for noen år siden omtalt som «Nord-Europas største åpne russcene». Det var åpenlys omsetning og bruk av illegale rusmidler og stor menneskelig nød. Heroin hadde over flere tiår vært det dominerende rusmiddelet. I 2012 inngikk Bergen kommune, politiet og Helse Bergen et forpliktende samarbeid for å få til en langsiktig løsning på utfordringene. Året før hadde Christian påtatt seg det medisinskfaglige ansvaret for legemiddelassistert rehabilitering (LAR) i Bergen.

- Min opprinnelige stillingsinstruks var å vurdere pasientene for inntak til legemiddelassistert rehabilitering. På denne tiden foregikk det en nasjonal dreining fra strenge inntaksvilkår til mer overkommelige krav.

\section{Christian Ohldieck}

\section{Født 1974}

Cand.med., Universitetet i Bergen 2003

Turnustjeneste, Kristiansund og Averøya 2004-06

Fastlege, Minde Medisinske Senter 2006-11

Overlege, Stiftelsen Bergensklinikkene 2006-09

Seksjonsleder, Avdeling for rusmedisin (AFR), LAR 2011-d.d.

Assisterende avdelingsdirektør, Avdeling for rusmedisin 2014-19

Spesialist i rus- og avhengighetsmedisin 2016

Seniorrådgiver, Helsedirektoratet 2019-d.d.

Nygårdsparken ble stengt i 2014, samtidig som Helsedepartementet besluttet at ansvaret for LAR-behandling skulle flyttes fra kommunalt nivå til helseforetakene. Dermed satt Christian midt i smørøyet for å få boltre seg i enda mer fagutvikling, vel vitende om at forskning hadde vist at legemiddelassistert rehabilitering var en nøkkelfaktor for å lykkes med å hjelpe de rusmiddelavhengige og å avvikle åpne russcener.

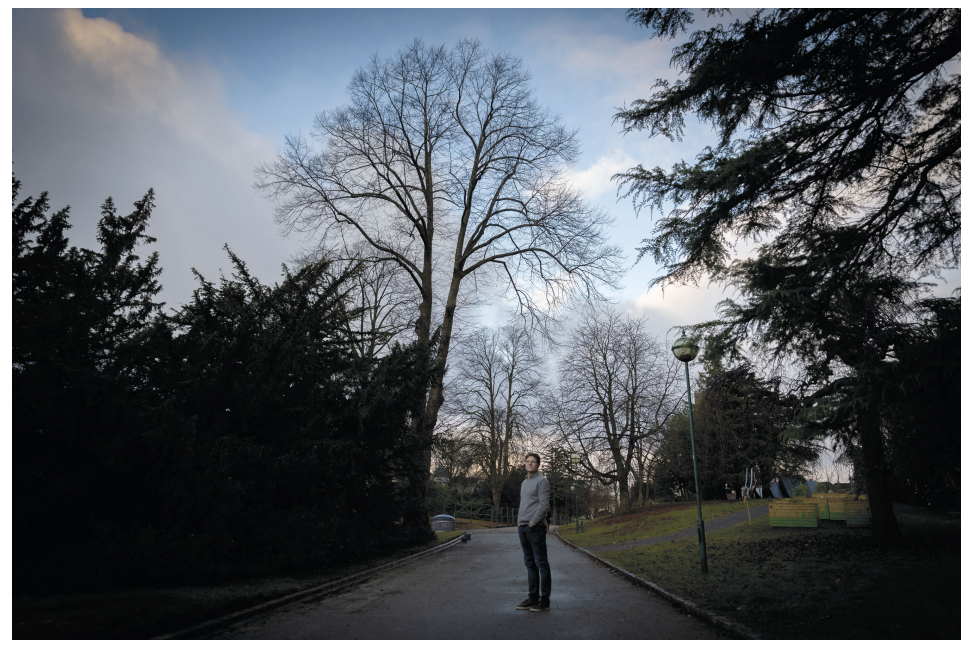

\section{Nye toner}

Våren 2014 var Christian i pappaperm med parets fjerde barn. Som rutinert bleieskiftarbeider fant han rikelig med tid til å tenke lange tanker og legge langsiktige planer.

- Jeg fikk gehør for en strategi om å nå frem til flest mulig heroinavhengige med legemiddelassistert rehabilitering. Vi startet den første lavterskelenheten i landet der opioidavhengige kunne møte opp uten timeavtale for å bli vurdert for dette tilbudet $\mathrm{i}$ spesialisthelsetjenesten. At det også ble tilbudt poliklinisk oppstart på metadon uten krav til rusfrihet, var nytt i Norge. I Bergen steg antallet i LAR-behandling fra 535 pasienter i 2011 
til 1 o6o i 2016.

Satsningen hadde også betydning på et samfunnsmedisinsk nivå. Sammen med kollegene regnet han ut at ved å inkludere så mange opioidavhengige i tilbudet ble omsetningen av heroin i Bergen redusert med 2-30o millioner kroner per år.

Jeg ser mer og mer hvor viktig det er med ledelse

- Målet vårt var å punktere markedet. Dette er enkel markedstenkning, men i et LARperspektiv var det svært utradisjonelt å tenke slik. Hvis vi ikke gikk all in, ville det illegale markedet leve videre og rekruttere mange nye brukere. En som er avhengig av heroin «vil gå over Hardangervidden for å få tak i neste dose», som en av mine pasienter sa en gang. Men når man får metadon eller buprenorfin, forsvinner i all hovedsak behovet for heroin.

- Nå skal jeg ikke rosemale for mye, sier han litt beskjemmet over å skryte.

- Det er fortsatt heroin i Bergen, men i et mye mindre omfang enn for bare fem år siden.

- Opplevde dere ikke at mange pasienter falt fra når det bare var å banke på døra for å få LAR-behandling?

- Nei, vi opplevde ikke stort frafall. Det handler mye om at vi tok bort de fleste hindrene som tidligere hadde gjort det vanskelig for en del å starte opp. Vi krevde verken henvisning, rusfrihet eller urinprøver, og vi tilbød både buprenorfin og metadon med poliklinisk oppstart. Vi nådde en gruppe pasienter som ellers er vanskelig å nå.

\section{Farvel til klinikken}

Christian fikk posisjoner med stort ansvar og skjønte fort at han også måtte ta lederskap. Etter hvert så han at han gjorde mer nytte med å tenke system og strategi enn å holde fast på å jobbe klinisk.

- Jeg ser mer og mer hvor viktig ledelse er. Det er jo litt rart å tenke på at de to viktigste oppgavene jeg har hatt $\mathrm{i}$ jobben, rusmedisin og ledelse, er noe vi knapt lærte om på studiet. Det har vært learning by doing hele veien.

- Savner du klinisk praksis?

- Nei, det har vært så gøy å bidra til utviklingen av behandlingstilbud at jeg ikke har følt behov for å gå tilbake til klinisk arbeid. Legeidentiteten er imidlertid sterkt knyttet til pasientbehandling. Akkurat det er faset litt ut, men jeg har ikke sagt et endelig farvel til klinikken. Jeg skal innrømme at jeg av og til føler en frykt for å ha mistet kompetanse. Hva kan jeg egentlig?

Jeg skal innrømme at jeg av og til føler en frykt for å ha mistet kompetanse. Hva kan jeg egentlig?

Før Avdeling for rusmedisin i Bergen fikk det helhetlige ansvaret for disse pasientene, var det for mange usammenhengende pasientforløp.

- Mange av pasientene er ikke i stand til å møte opp til avtalt tid på ulike behandlingssteder. Helsetilstanden deres er ofte så sammensatt at det faglig sett er nødvendig med mange ulike behandlingstilbud. I stedet for at de skulle møte opp for LAR-legemiddel og sosialfaglig oppfølging ett sted, legetime et annet og psykologbehandling et tredje, valgte vi en modell der alle spesialisthelsetjenestetilbudene ble lagt dit pasientene kom hver dag: der de mottok LAR-legemiddelet.

\section{Unikt forskningsmateriale}

Med LAR-poliklinikker i hver bydel, hvor pasientene møter flere ganger ukentlig og etablerer langvarige og tillitsfulle relasjoner til behandlerne, lå forholdene særlig godt til rette for forskning. En høsthelg for noen år tilbake dro Christian sammen med sin venn, kollega og professor Kjell Arne Johansson til Finse for å sykle Rallarvegen med barna. 


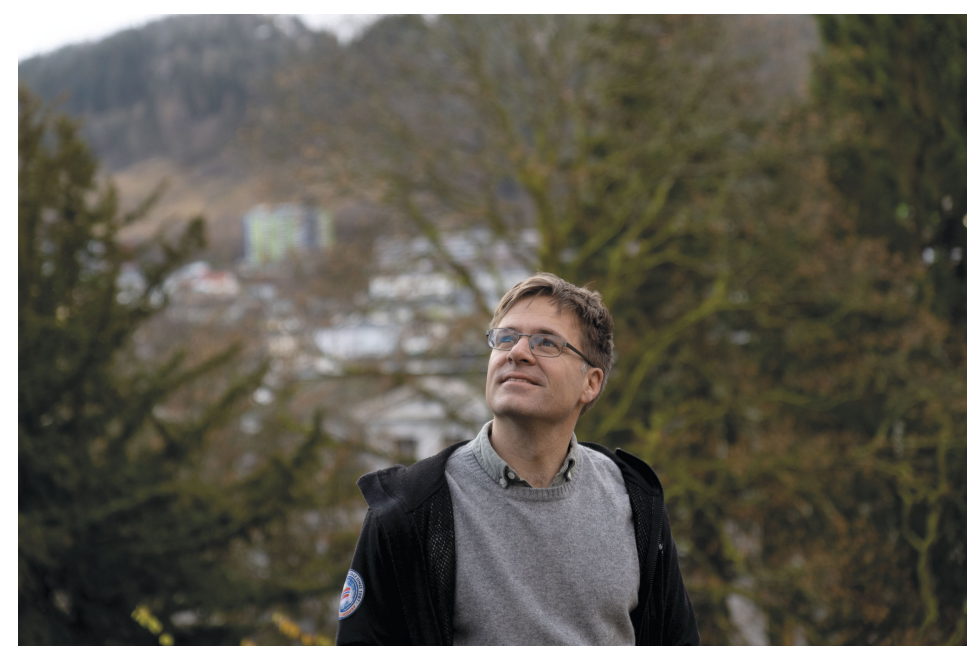

- Når sant skal sies, fikk barna en mer eller mindre voksenfri tid på deler av turen mens vi klekket ut planen om en randomisert kontrollert studie på integrert behandling for hepatitt C i LAR-poliklinikkene. Æren for at studien nesten er gjennomført, er det andre i avdelingen som skal ha, men Kjell Arne og jeg synes fortsatt det er gøy å tenke på hvordan det hele startet.

Sikre kilder forteller at Christian på samme tur hadde glemt å ta med mat til barna. Han bare smiler når jeg spør om dette stemmer, og innrømmer at når det blir rom for faglige samtaler, er det lett å glemme tid og sted.

- Jeg har nok evne til å bli veldig faglig engasjert. Faget er jo så spennende.

\section{Vandring og mindfulness}

- Blir du aldri sliten?

- Jeg merker at jeg ikke lenger klarer å jobbe effektivt med faglige ting om kveldene og at jeg blir mer og mer avhengig av mine turer i fjellene rundt Bergen. Fysisk aktivitet er essensielt for meg for å få løst vanskelige problemstillinger. Jeg tenker på alt mellom himmel og jord når jeg går, men underbevisstheten jobber likevel godt med de vanskelige tingene.

- Jeg elsker fjellet! utbryter han og legger vekt på at det handler om å vandre, ikke trene.

- Jeg skal jo ikke vinne noe som helst, hvorfor skal jeg da presse meg til hard trening?

Han forteller at han noen måneder i studietiden reiste rundt i Asia.

En måned tilbrakte han i et buddhistisk tempel i Thailand der de praktiserte det som i Vesten i dag kalles mindfulness.

- Kan vandring sies å være en form for mindfulness?

- Nei, det er ikke helt det samme. Mindfulness har en annen dybde. Men jeg forsøker å praktisere begge deler og opplever at det er svært nyttig.

- Mange år i krevende posisjoner har vel kostet litt, hva har din kone sagt om dette?

- Jeg har nok i mange år vært litt mer fraværende, fysisk eller åndelig, enn det som godt er . Hun har støttet meg og hjulpet meg til å få en bedre balanse mellom jobb og familieliv. Et godt ekteskap er en viktig grunnmur i et slikt liv som jeg lever.

Så legger han til:

- Det er nok det sosiale som dessverre i stor grad har blitt prioritert bort. Det har vært et bevisst valg, siden faget ble så spennende, men det har sin pris.

\section{Oksykontinbølgen}

Bølgen i USA med pasienter som har utviklet avhengighet på grunn av oksykontinforskrivning har heldigvis ikke nådd landet vårt med samme tyngde. Vi har 
likefullt en del pasienter som er blitt avhengige av smertestillende legemidler. Til nå har de ikke fått et tilstrekkelig tilpasset behandlingstilbud.

- I arbeidet med nye retningslinjer vurderes det om en del av disse pasientene bør tilbys legemiddelassistert rehabilitering, forteller Christian.

- Disse utgjør en annen utfordring enn pasienter som har vært heroinavhengige. De fleste pasienter som bruker høye doser opioider mot smerte over tid, utvikler toleranse for stoffene, og mange er redd for å gå ned i dose. Å avklare om de tilfredsstiller kriteriene for avhengighetssyndrom, kan være krevende.

- Du liker å gruble på utfordringer i faget?

- Jeg vil ikke kalle meg grubler. Jeg liker å utvikle og gjennomføre strategier, og jeg forsøker å unngå å bli lammet av alt som skjer her og nå. Det er en utfordring å være på begge plan samtidig. Mange ganger er jeg nok litt for mye i høyden.

Det er viktig å ikke grave seg ned i det vi ikke mestrer

Han fortsetter:

- Hvordan skal vi plassere de små valgene i det store bildet? Det må jo til for å få det til å passe. Jeg mener også at det er viktig å ikke grave seg ned i det vi ikke mestrer. Vi må evne å se det som går bra også. Heldigvis har vi vært en leder- og ansattgruppe som har hatt mottoet «Dette får vi til!»

Det siste året har Christian hatt delvis permisjon fra lederjobben, siden han ble hyret inn som seniorrådgiver i Helsedirektoratet for å lede arbeidet med revisjon av de nasjonale retningslinjene for legemiddelassistert rehabilitering. Han var også faglig leder for revisjonen av deler av retningslinjene for denne behandlingen hos gravide, et tema med mange kontroverser.

- Det var et spennende og krevende arbeid, som heldigvis til slutt landet på en måte som vi mener er til det beste for både mor og foster/barn.

Faget har blitt en dominerende del av Christians liv.

- Det har nok kommet litt under huden. I mange år gikk jeg sånn inn i rollen at det nærmest ble min identitet. Siden jeg har vært så heldig å være med på å skape noe, har jeg opplevd et nært forhold og sterkt eierskap til jobben.

Christian oppsummerer:

- Det oppstod muligheter for å utvikle tjenestetilbudet og bedre helsehjelpen til en utsatt pasientgruppe som samtidig ga meg anledning til å bruke mange sider av meg selv. Sammen med nære, gode medarbeidere grep jeg tak i disse mulighetene og fylte dem med retning, struktur og innhold. Jeg har tenkt at det for meg har vært en once in a lifetimemulighet til virkelig å bidra substansielt. Men hvem vet, kanskje kan det oppstå nye slike muligheter? Jeg håper i hvert fall at jeg ikke slutter å se etter dem.

Vi tar farvel etter en innholdsrik samtale. Christian skal på et møte i byen. Med den største selvfølge tar han fram paraplyen på årets kanskje fineste solskinnsdag. Livet har nok lært ham at regnet i Bergen kan komme når man minst venter det. Så er det altså noe her i livet han ikke prøver å få kontroll over med gode, framsynte strategier.

Publisert: 23. januar 2020. Tidsskr Nor Legeforen. DOI:10.4045/tidsskr.19.0736

(C) Tidsskrift for Den norske legeforening 2020. Lastet ned fra tidsskriftet.no 